\title{
Epidemiological profile of patients waiting for penetrating keratoplasty in state of Pernambuco - Brazil
}

\author{
Perfil epidemiológico de pacientes na fila de transplante \\ de córnea no estado de Pernambuco - Brasil
}

Hirlana Gomes Almeida', Ana Catarina Delgado de Souza²

\begin{abstract}
Purpose: To describe the epidemiological profile of patients waiting for penetrating keratoplasty in state of Pernambuco, Brazil. Methods: Transversal and retrospective study, with 871 patients, in the period of 06/01/2011 a 05/31/2012, were registered on the waiting list for corneal transplantation in the Central of Notification, Captation and Distribution of Organs (CNCDO) of Pernambuco. Registration forms of cornea receiving were used, adapted to the purposes of this research. Results: In relation to frequency, it was obtained $54 \%$ female, $35 \%$ aged 61 to 80 years; $60 \%$ transplanted; $52 \%$ from the metropolitan area of Recife; $57 \%$ that waited 1 to 6 months the transplant; $82 \%$ with optical indication for transplant, 5\% with priority on the waiting list (48\% of those with ocular perforation) and; $37 \%$ whose transplant center was the Fundação Altino Ventura (FAV). The main indications for corneal transplantation were leukoma (33\%), keratoconus (22\%) e bullous keratopathy (18\%). Conclusion: It was found that most patients were aged 61 to 80 years; was from the metropolitan area of Recife; was submitted to corneal transplantation; waited for one to six months to do the transplantation; had the diagnosis leukoma, followed by keratoconus and bullous keratopathy; was indicated to transplantation optical and had the transplant center to FAV.
\end{abstract}

Keywords: Health profile; Corneal diseases; Corneal transplantation/epidemiology

\section{RESUMO}

Objetivo: Descrever o perfil epidemiológico de pacientes na fila de transplante de córnea no Estado de Pernambuco, Brasil. Métodos: Estudo transversal e retrospectivo realizado no período 01/06/2011 a 31/05/2012, com 871 pacientes cadastrados na fila de espera para transplante de córnea na Central de Notificação, Captação e Distribuição de Órgãos de Pernambuco (CNCDO/PE). Os dados foram coletados por meio de protocolos baseados nas fichas de cadastro de receptor de córnea. Resultados: Em relação à frequência, obteve-se $54 \%$ do gênero feminino, 35\% na faixa etária de 61 a 80 anos; $60 \%$ transplantados; $52 \%$ provenientes da região Metropolitana do Recife; $57 \%$ que aguardaram 1 a 6 meses o transplante; $82 \%$ com indicação de transplante óptico; $5 \%$ com prioridade na fila de espera (destes $48 \%$ por perfuração ocular) e; $37 \%$ cujo centro transplantador era a Fundação Altino Ventura (FAV). As principais indicações para transplante de córnea foram leucoma (33\%), ceratocone (22\%) e ceratopatia bolhosa (18\%). Conclusão: Verificou-se que a maioria dos pacientes encontra-se na faixa etária de 61 a 80 anos; era da Mesorregião Metropolitana de Recife; foi submetida ao transplante de córnea; aguardou de um a seis meses para realizar o transplante; teve como diagnóstico o leucoma, seguido por ceratocone e ceratopatia bolhosa; teve como indicação o transplante óptico e teve como centro transplantador a FAV.

Descritores: Perfil de saúde; Doenças da córnea; Transplante de córnea/epidemiologia

\footnotetext{
${ }^{1}$ Altino Ventura Foundation, Recife/PE, Brazil.

${ }^{2}$ Federal University of Pernambuco, Recife/PE, Brazil.
}

Work conducted at the Organ Notification, Collection, and Distribution Centre of Pernambuco, Recife/PE, Brazil.

The authors declare no conflicts of interest

Received for publication: 14/3/2013 - Accepted for publication: 23/10/2013

Rev Bras Oftalmol. 2014; 73 (1): 28-32 


\section{INTRODUCTION}

$\mathbf{C}$ orneal diseases are the second leading cause of revers ible blindness worldwide. They affect a young and active population, producing an important economic and social burden. Despite current efforts, there is still a lack of donor tissues and eye banks to provide corneas in adequate number and quality for transplantation ${ }^{(1)}$.

Spain is a world reference in organ collection, and the Spanish National Transplant Organisation determines that all hospitals must have a Hospital Transplant Commission. Since the establishment of these commissions from 1989 to 2001, the number of organ donors increased from 14 to 32.5 per million inhabitants $^{(2)}$.

The number of corneal transplants is growing each year in Brazil. In 2008, 13,341 transplants were performed, and by 2011 the number had increased to $14,696^{(3)}$. In the State of Pernambuco there were 1,215 patients awaiting corneal transplantation at the end of 2011, but only 661 transplants were performed that year ${ }^{(4)}$. However, the greatest obstacle to an increase in donations is the lack of informed donors ${ }^{(5)}$.

The indications for penetrating keratoplasty vary in different regions of Brazil. Keratoconus is the main indication in São Paulo $^{(6)}$, while in Sergipe the most frequent indication is bullous keratopathy, and keratoconus is the third most common indica$\operatorname{tion}^{(7)}$.

The number of surgical organ and tissue transplants has been shown to be increasing in recent decades. Corneal transplantation is the most common because of its easier technique and the number of donated organs ${ }^{(6)}$.

The present study aimed to delineate the epidemiological profile of patients awaiting corneal transplantation in the State of Pernambuco, Brazil.

\section{METHODS}

This was a cross-sectional retrospective study that included 871 patients registered on the waiting list for keratoplasty in the Organ Notification, Collection, and Distribution Centre (CNCDO) of Pernambuco from June 1, 2011 to May 31, 2012.

Patients whose registration data were incomplete and those with diagnoses inconsistent with indications for transplantation according to Ordinance 2600 were excluded from the study. ${ }^{(8)}$

Data were collected between June and August 2012 from the electronic registration records of cornea recipients in $\mathrm{CNCDO} / \mathrm{PE}$, adapted to the study objectives.

Study variables included sex, age, origin, ophthalmic diagnosis, date of inclusion in $\mathrm{CNCDO}$, date of transplantation, time on the waiting list until transplantation, status on the waiting list, transplantation centre, indication, and transplantation priority.

According to Ordinance $2600^{(8)}$, potential cornea recipients can be classified on the Single Technical Registry as active, semi-active and removed. In this study, however, recipients were classified according to their situation on the waiting list as semiactive, suspended, dropout, and transplanted, as it is essential to know the number of transplants performed and the number of subjects who chose not to undergo transplantation.

Data were analysed using descriptive statistics methods. Charts and tables were prepared using Microsoft Excel ${ }^{\mathrm{TM}} 2007$ software.
Table 1

Origin of patients registered in the Organ Notification, Collection, and Distribution Centre

\begin{tabular}{lcc}
\hline Region in Pernambuco State & N & \% \\
\hline São Francisco & 59 & 7 \\
Sertão & 52 & 6 \\
Agreste & 147 & 17 \\
Mata & 78 & 9 \\
Recife Metropolitan Area & 455 & 52 \\
Other States* & 80 & 9 \\
Total & $\mathbf{8 7 1}$ & $\mathbf{1 0 0}$ \\
\hline
\end{tabular}

*Other States: Alagoas, Paraíba, Bahia, Sergipe, Piauí, Ceará, Roraima, and Amapá

Table 2

Waiting time for patients registered in the Organ Notification, Collection, and Distribution Centre

\begin{tabular}{lcc}
\hline Waiting Time & N & \% \\
\hline Up to 29 days & 153 & 29 \\
1-6 months & 302 & 57 \\
$7-11$ months & 68 & 13 \\
1-3 years & 4 & 1 \\
Total & $\mathbf{5 2 7}$ & $\mathbf{1 0 0}$ \\
\hline
\end{tabular}

Table 3

Diagnosis of patients registered in the Organ Notification, Collection, and Distribution Centre

\begin{tabular}{lcc}
\hline Diagnosis & Quantidade & \% \\
\hline Bullous keratopathy & 155 & 18 \\
Leukoma & 288 & 33 \\
Fuchs dystrophy & 69 & 8 \\
Keratoconus & 188 & 22 \\
Other* & 15 & 2 \\
Other corneal dystrophies & 70 & 8 \\
Secondary or late failure & 86 & 10 \\
Total & $\mathbf{8 7 1}$ & $\mathbf{1 0 0}$ \\
\hline
\end{tabular}

Other: keratitis and degeneration

\section{RESULTS}

Of the 871 study subjects, $54 \%$ were female; $35 \%$ were aged $61-80$ years; $52 \%$ came from the Recife Metropolitan Area (Table 1); $60 \%$ had undergone transplantation, followed by $33 \%$ whose status was semi-active; $57 \%$ waited $1-6$ months until transplantation (Table 2); $33 \%$ had a diagnosis of leukoma, followed by $22 \%$ with keratoconus and $18 \%$ with bullous keratopathy (Table 3).

Regarding the indications for transplantation, $82 \%$ were optical and $18 \%$ were tectonic, of which only $5 \%$ had priority status on the waiting list: $48 \%$ due to ocular perforation and $39 \%$ due to primary graft failure requiring retransplantation (Table 4). 
Table 4

\section{Reasons for priority transplantation among patients registered in the Organ Notification, Collection, and Distribution Centre}

\begin{tabular}{|c|c|c|}
\hline Reason for priority & $\mathbf{N}$ & $\%$ \\
\hline Ocular perforation & 21 & 48 \\
\hline Descemetocele & 4 & 9 \\
\hline $\begin{array}{l}\text { Corneal ulcer } \\
\text { unresponsive to treatment }\end{array}$ & 2 & 5 \\
\hline $\begin{array}{l}\text { Retransplantation after } \\
\text { primary graft failure }\end{array}$ & 17 & 39 \\
\hline Total & 44 & 100 \\
\hline
\end{tabular}

Table 5

Transplant centre of patients registered in the Organ Notification, Collection, and Distribution Centre

\begin{tabular}{lcc}
\hline Transplant centre & $\mathbf{N}$ & \% \\
\hline FAV & 323 & 37 \\
HOPE & 99 & 11 \\
IOR & 89 & 10 \\
OTHER & 203 & 23 \\
CMOV & 85 & 10 \\
IMIP & 72 & 8 \\
Total & $\mathbf{8 7 1}$ & $\mathbf{1 0 0}$ \\
\hline
\end{tabular}

IMIP: Integral Medicine Institute Professor Fernando Figueira; CMOV: Eye Clinic of São Francisco Valley; IOR: Recife Eye Institute; HOPE: Pernambuco Eye Hospital;FAV: Altino Ventura Foundation.

*Other: SEOPE: Pernambuco Eye Service; COC: Caruaru Eye Clinic; HOSL: Santa Luzia Eye Hospital; CSSHM: Senator Hermínio de Moraes Health Centre; RHP: Portuguese Royal Hospital; HC: University Hospital

The main transplant centre in the state of Pernambuco was the Altino Ventura Foundation with $37 \%$ of transplants (Table 5).

\section{Discussion}

Corneal transplantation is the most successful procedure among tissue transplants in humans. Its goal is restoration of corneal transparency ${ }^{(9)}$.

According to some authors ${ }^{(10)}$, the consistent progress in techniques, organ processing, assessment, and conservation of corneas have led to an increase in the number of corneal transplants performed in Brazil ${ }^{(11)}$ and in the State of Pernambuco ${ }^{(3)}$ and to a significant improvement in postoperative outcomes.

Moreover, there is greater public awareness of current treatment prospects and improved education of health care professionals with regard to the importance of cornea donation ${ }^{(12)}$, which helps increase the number of procedures performed in the country. Our results show a slight predominance of females among transplant patients. Previous studies conducted in Brazilian reference centres for corneal transplantation also found a predominance of females ${ }^{(13-15)}$, while others found a predominance of males ${ }^{(12,16,17)}$. This variability depends on the region, the studied population, and the time when the study was conducted.
Most patients were aged 61-80 years, confirming the findings of a study conducted in the Eye Bank of Base Hospital in São José do Rio Preto ${ }^{(16)}$ and showing that the mean age of transplant patients tends to be high. This can be explained by the ageing of the population in Brazil, which in 2009 had a life expectancy of 73 years $^{(18)}$, as well as the increased awareness of patients regarding the treatment and prevention of ocular disor$\operatorname{ders}^{(16)}$

According to Ordinance $2600^{(8)}$, potential cornea recipients can be classified on the Single Technical Registry as active (able and available for transplantation), semi-active (incomplete pre-transplant workup, suspended by the medical team, or without clinical conditions), and removed (treatment dropout, refusal of transplantation, systematic refusals, prolonged semi-activity, removed by staff, removed due to lack of clinical conditions, transferred to another state, transplanted in another state, and transplanted abroad).

A patient removed due to prolonged semi-activity is a potential transplant recipient who has had a semi-active status for 120 cumulative days. A patient removed due to systematic refusal is a potential transplant recipient who has accumulated five refusals by the medical team to tissue offers by $\mathrm{CNCDO}$ from different donors at different dates ${ }^{(8)}$.

In our study there was a significant predominance of transplanted patients, underscoring the increasing number of transplants performed in the State of Pernambuco. However, the number of transplants is still far from ideal, as a third of subjects still had a semi-active status. This shows that the number of transplants performed in Brazil and worldwide is still insufficient for the number of patients on waiting lists ${ }^{(10)}$. This reflects the Brazilian reality where, despite efforts, there is still an unfortunate lack of donated tissues and eye banks to provide corneas in adequate number and quality for transplantation ${ }^{(1)}$.

According to the Brazilian Ministry of Health ${ }^{(19)}$, in the Brazilian public health system the transplant waiting list for each organ or tissue is unique, and transplants are made on a firstcome basis considering urgency and technical and geographic criteria.

Waiting lists result from a mismatch between demand and supply, and treatment delays have an adverse impact on therapy, the chances of cure, the nature and extent of disabilities, and the bio-psycho-social well-being of patients, family members, and society as a whole ${ }^{(20)}$.

Our results show that most patients wait at most six months before undergoing corneal transplantation. This finding is in contrast with a study conducted in the state of Pará on 1271 patients, of which more than half had to wait 1-3 years before undergoing penetrating keratoplasty ${ }^{(21)}$.

The results of our study corroborate data from the Brazilian Association of Organ Transplantation which show that the number of corneal transplants has been increasing every year in Brazil $^{(3)}$.

This progressive increase in the number of penetrating keratoplasties is due to several factors, including population ageing; better organisation of eye banks; better selection of donated tissues; and advances in pharmacology, immunology and ocular microsurgery, thanks to which transplants can be done in situations previously considered inoperable ${ }^{(11,22)}$.

However, in most Brazilian transplant centres the waiting period is still long and quite sensitive to variations in organ supply and demand. To reduce delays, national and international policies are needed to encourage donation and to reduce fears and insecurities on the part of the families of potential donors ${ }^{(23)}$.

In a study with 42 patients submitted to penetrating kerato- 
plasty, most were unaware of the actual importance of a transplant, revealing the lack of communication between doctors and patients, which leads to poor understanding of the types of corneal disease. This situation impairs proper recovery, even though most patients were satisfied with the outcome of surgery, albeit without the desired optical correction ${ }^{(24)}$.

The knowledge and understanding a patient has of corneal transplantation is as important as the surgical technique itself. The lack of information on corneal transplantation and little awareness about the severity of the disease can lead to false expectations and failure to adhere to postoperative care and follow-up visits, which may compromise the surgical outcome and cause frustration ${ }^{(13)}$.

Therefore, patients awaiting transplantation should receive effective information prior to surgical treatment regarding their eye condition, the proposed procedure, intra- and postoperative care and risks, and the prospects for visual rehabilitation through educational lectures given by health care professionals ${ }^{(13,24)}$.

The State of Pernambuco is located in the northeast of Brazil and is divided into the following regions: São Francisco, Sertão, Agreste, Mata, and the Recife Metropolitan Area ${ }^{(25)}$. In our study, most patients came from the Recife Metropolitan Area, as this population has greater access to public health services for the diagnosis, treatment, and monitoring of eye conditions.

It is important to note that $10 \%$ of patients transplanted in Pernambuco came from other Brazilian states, demonstrating the inability of other states to meet their demand for corneal transplants, thus overloading the health care systems of nearby states.

The most frequent indications for corneal transplantation may vary depending on the moment a study was conducted, data collection sites, population age, and environmental and cultural factors, among others ${ }^{(11)}$.

It is therefore crucial to determine the indications for transplantation in order to adequately manage patients and improve their quality of life.

In our study, the main indication for corneal transplantation in the State of Pernambuco was leukoma, followed by keratoconus and bullous keratopathy.

This finding is in contrast with several studies in other parts of Brazil, Latin America and Europe, where keratoconus is the primary indication for corneal transplantation ${ }^{(6,26,27)}$. This can be attributed to better adaptation to and quality of contact lenses for visual correction as well as the use of intrastromal rings ${ }^{(28)}$, which decrease the number of keratoconus patients undergoing transplantation.

Importantly, in another study conducted in the state of Pernambuco from January 1998 to December 2002, ulcerative lesions were important causes of corneal transplantation ${ }^{(28)}$. In our study we found no such lesions, showing that the treatment corneal ulcers has improved. However, it is worth noting that treated ulcers may produce scarring leading to leukoma.

With regard to the types of transplantation, we found a significant prevalence of optic indications. The main transplant centre in the state of Pernambuco was the Altino Ventura Foundation, responsible for almost half of transplants. This Foundation is headquartered in Recife and has clinics in other locations (Jaboatão dos Guararapes, Paulista, Salgueiro, and Arcoverde); it has been providing free health care to the population of the state for 26 years, with emergency care, outpatient units, and surgical procedures.

The importance of corneal transplantation should be better publicised and clarified in order to raise awareness, inform, and motivate potential donors. With this, the visual recovery and quality of life of patients would not be limited by the lack of available tissues for transplantation ${ }^{(10)}$.
Moreover, due to the high number of patients awaiting penetrating keratoplasty on the waiting list of CNCDO in the State of Pernambuco, health care professionals should be trained and educational campaigns should be undertaken to raise awareness on the need and importance of organ donation.

\section{Conclusion}

Among patients registered in the CNCDO of Pernambuco, most were aged 61-80 years; came from the Recife Metropolitan Area; were submitted to corneal transplantation during the study period; waited 1-6 months until transplantation; had a diagnosis of leukoma, followed by keratoconus and bullous keratopathy; had an optical indication for transplantation; did not get priority status on the waiting list, and, when they did, it was due to ocular perforation, followed by primary graft failure requiring retransplantation.

We also found that the main transplant centre in the state of Pernambuco was the Altino Ventura Foundation and that, among transplanted patients, the waiting time for corneal transplantation was inappropriately long.

\section{Acknowledgements}

The author would like to thank Professor Ana Catarina Delgado de Souza, Ph.D., director of the Recife Eye Bank, for dedicating her time and expertise to this work and the staff of $\mathrm{CNCDO} / \mathrm{PE}$ who contributed with the data collection for this study.

\section{ReFERENCES}

1. Adán CBD, Diniz AR, Sato EH. [Ten years of corneal donation to the Hospital São Paulo Eye Bank: characteristics of cornea donors from 1996 to 2005]. Arq Bras Oftalmol. 2008;71(2):176-81. Portuguese.

2. Matesanz R, Miranda B. A decade of continuous improvement in cadaveric organ donation: the Spanish model. J Nephrol. 2002;15(1):22-8.

3. Associação Brasileira de Transplantes de Órgãos. Registro Brasileiro de Transplantes: Janeiro/Dezembro 2011. [Internet]. [citado 2012 mar 3];17(4):[cerca de 35 p]. Disponível em: http://www.abto.org.br/abtov02/ portugues/populacao/rbt/mensagemRestrita.aspx?idCategoria $=2$.

4. Pernambuco. Central de Transplantes. Doações e Transplantes em Pernambuco. Órgãos e tecidos transplantados em Pernambuco de 1995 a 2012. [Internet]. [citado 2012 mar 3]. Disponível em: http:// www.transplantes.pe.gov.br/estatistica.htm.

5. Coelho JC, Cilião C, Parolin MB, Freitas AC, Gama Filho OP, Saad DT et al. [Opinion and knowledge of the population of a brazilian city about organ donation and transplantation]. Rev Assoc Med Bras. 2007;53(5):421-5. Portuguese.

6. Flores VG, Dias HL, Castro RS. [Penetrating keratoplasty indications in "Hospital das Clínicas-UNICAMP"]. Arq Bras Oftalmol. 2007;70(3):505-8. Portuguese.

7. Araújo AA, Melo GB, Silva RL, Araújo Neta VM. Epidemiological profile of the patients on the waiting list for cornea transplantation in the State of Sergipe, Brazil]. Arq Bras Oftalmol. 2004;67(4):613-6. Portuguese.

8. Brasil. Ministério da Saúde. Portaria $\mathrm{n}^{\circ} 2.600$, de 21 de Outubro de 2009. Aprova o regulamento técnico do sistema nacional de transplantes [Internet]. Diário Oficial da União, Brasília (DF). [citado 2009 Out 30]. Disponível em: http://www.brasilsus.com.br/legislacoes/ gm/101249-2600.html.

9. Chalita MR, Diazgranados EB, Sato EH, Branco BC, Freitas D. [Corneal graft rejection after penetrating keratoplasty: analysis of the Eye Bank of the Hospital Säo Paulo - Escola Paulista de Medicina]. Arq Bras Oftalmol. 2000;63(1):55-8. Portuguese. 
10. Rodrigues AM, Sato E. [Knowledge of the intensive care physicians on corneal donation]. Arq Bras Oftalmol.2003;66(1):29-32. Portuguese.

11. Sano FT, Dantas PE, Silvino WR, Sanchez JZ, Sano RY, Adams F, et al. [Trends in the indications for penetrating keratoplasty]. Arq Bras Oftalmol. 2008;71(3):400-4. Portuguese.

12. Neves RC, Boteon JE, Santiago AP. Indicações de transplante de córnea no Hospital São Geraldo da Universidade Federal de Minas Gerais. Rev Bras Oftalmol. 2010;69(2):84-8.

13. Kara-Junior N, Mourad PC,Espíndola RF,AbilRuss HH. [Expectation and knowledge among patients with keratoplasty indication]. Rev Bras Oftalmol. 2011;70(4):230-4. Portuguese.

14. Tonhá CD, Santos AM, Souza JC, Muniz MC. [Retrospective study of corneal transplants in the state of Alagoas]. J Bras Transpl. 2010;13:1216-9. Portuguese.

15. Quinto GQ, Fonseca LE. [Therapeutic keratoplastyïs indication in and Ophthalmologic Hospital of Porto Alegre]. Rev Bras Oftalmol. 2006;65(2):82-6. Portuguese.

16. Barbosa, AP, Almeida Júnior GC, Teixeira MF, Barbosa JC. [Evaluation of penetrating keratoplasty indications in inner part of the São Paulo state]. Rev Bras Oftalmol. 2012;71(6):353-7. Portuguese.

17. Sano RY, Sano FT, Dantas MC, Lui AC, Sano ME, Lui Neto A. [Analysis of the transplanted corneas at Santa Casa de São Paulo Eye Bank]. Arq Bras Oftalmol. 2010;73(3):254-8. Portuguese.

18. Torres D. Brasil tem quase 4 milhões de mulheres a mais que homens. Ultimo Segundo (São Paulo) [Internet]. 2011 [citado 2011 abr 29]; Abr 29: [cerca de 1 p.]. Disponível em:http://ultimosegundo.ig.com.br/brasil/ brasil+tem+quase+4+milhoes+de+mulheres+a+mais+que+homens/ n1300118028219.html.

19. Brasil. Ministério da Saúde. Portaria n. 91-GM, de 23 de janeiro de 2001. Dispõe sobre a remoção de órgãos, tecidos e partes do corpo humano para fins de transplante e tratamento e dá outras providências [Internet]. Diário Oficial da União, Brasília (DF); 2001 Jan 24 [citado 2012 Ago 23]. Disponível em: http://dtr2001.saude.gov.br/sas/ PORTARIAS/Port2001/Gm/GM-091.htm.

20. Marinho A. [A study on organ transplantation waiting lines in Brazil's Unified National Health System]. Cad Saúde Pública. 2006;22(10):2229-39. Portuguese.
21. Almeida Sobrinho EF, Negrão BC, Almeida HG. [Epidemiological profile of patients waiting for penetrating keratoplasty in state of Pará, Brazil]. Rev Bras Oftalmol. 2011;70(6):384-90. Portuguese.

22. Cattani S, Kwitko S, Kroeff MA, Marinho D, Rymer S, Bocaccio FL. [Indications for corneal graft surgery at the Hospital de Clínicas of Porto Alegre]. Arq Bras Oftalmol. 2002;65(1):95-8. Portuguese.

23. Farias RJ, Sousa LB. [Marketing role of corneal graft tissue donation to an eye bank and donors']. Arq Bras Oftalmol. 2008;71(1):28-33. Portuguese.

24. Moreno GL, Souza LB, Freitas D, Sato EH, Vieira LA. [Corneal transplant and what the patients know about it]. Arq Bras Oftalmol. 2003;66(6):797-801. Portuguese.

25. Mesorregiões de Pernambuco [mapa]. Recife: Governo do Estado de Pernambuco, Agencia Estadual de Planejamento e Pesquisa de Pernambuco; 2006. 1 Mapa: 1:800.000. colorido.Calix Netto MJ, Giustina ED, Ramos GZ, Peccini RF, Sobrinho M, Souza LB. [Major indications for corneal penetrating keratoplasty at a reference service in São Paulo state (Sorocaba - SP, Brazil)]. Arq Bras Oftalmol. 2006;69(5):661-4. Portuguese. English.

26. Endriss D. Cunha F, Ribeiro MP, Toscano J. [Penetrating keratoplasties performed at the Fundação Altino Ventura: review of results and complications]. Arq Bras Oftalmol. 2003;66(3):273-7. Portuguese.

27. Gonçalves ED, Campos M, Paris F, Gomes JA, Farias CC. [Bullous keratopathy: etiopathogenesis and treatment]. Arq Bras Oftalmol. 2008;71(6, Supl.):61-4. Portuguese.

28. Amaral CS, Duarte JY, Silva PL, Valbuena R, Cunha F. [Indications for penetrating keratoplasty in Pernambuco]. Arq Bras Oftalmol. 2005;68(5):635-7. Portuguese.

\section{Corresponding author:}

Hirlana Gomes Almeida

Rua dos Médicis, 30, apto. 903 -

CEP: 50070-290 - Recife/PE, Brazil

Tel: +558130491907

E-mail: hirlanaa@hotmail.com 